\title{
Kulturskolens kompetansebehov for ny rammeplan. En regional undersøkelse i Buskerud, Telemark og Vestfold
}

\author{
Anders Rønningen \\ Universitetet $i$ Sørøst-Norge
}

\begin{abstract}
Sammendrag
Selv om kulturskolepedagogene regnes for å ha høy kompetanse, er det ikke forsket så mye på hvorvidt kompetansen er godt innrettet for å løse de oppgavene kulturskolen skal løse. Den nye rammeplan for kulturskolen (Norsk kulturskoleråd, 2016) styrker og justerer retningen for kulturskolenes samfunnsoppdrag, og gir dermed også føringer for hva som bør finnes både av formell og realkompetanse. Denne artikkelen undersøker hvordan kulturskolerektorer i Buskerud, Telemark og Vestfold (BTV) tolker kompetansesituasjonen i sine institusjoner i relasjon til rammeplanens krav og intensjoner. Forskningsprosjektet som ligger til grunn for denne artikkelen viser at rektorene erfarer et behov for justert og styrket kompetanse hos kulturskolepedagogene innenfor den delen av kulturskolens samfunnsoppdrag som er tettest på sosiale perspektiver, og at de formelle kompetansene som de ansatte har ikke nødvendigvis sikrer dette. I artikkelens siste og mer eksplorerende del, foreslås forklaringer på hvordan dette har oppstått og hvordan dette kan løses.
\end{abstract}

Nøkkelord: Kulturskole; kulturskoleledelse; rammeplan for kulturskolen; kompetanse $i$ kulturskolen; kulturskolepolicy

\begin{abstract}
Although the teachers in the Norwegian Schools of Music and Performing Arts [Kulturskolen] are considered to have high levels of competence, there is not much research available as to whether this competence is suitable for solving issues that the kulturskolen may face in the future. The new curriculum framework for the schools (Norsk kulturskoleråd, 2016) sets formal demands for the teachers' education and also - through its regulation of content - on the competencies that are needed in the schools. This article examines how the headmasters of the municipal kulturskole in three Norwegian counties - Buskerud, Telemark, and Vestfold - interpret the competency situation in their institutions in relation to the curriculum framework's requirements and intentions. The research project underlying this article shows that the principals feel that there is a need for adjusted and strengthened competence in their institutions in order to meet the increased focus on breadth and social aspects that is found in the curriculum framework. Their staff (the teachers) do not
\end{abstract}

Korrespondanse: Anders Rønningen, e-post: anders.ronningen@kulturskoleradet.no (C) 2019 A. Rønningen. This is an Open Access article distributed under the terms of the Creative Commons Attribution 4.0 International License (https://creativecommons.org/licenses/by-nc/4.0/), allowing third parties to copy and redistribute the material in any medium or format and to remix, transform, and build upon the material for any purpose, even commercially, provided the original work is properly cited and states its license.

Citation: A. Rønningen. «Kulturskolens kompetansebehov for ny rammeplan. En regional undersøkelse $i$ Buskerud, Telemark og

Vestfold». Fournal for Research in Arts and Sports Education, Special Issue: «Community Arts/Arts Education»Vol. 3(1), 2019, pp. 59-77. http://dx.doi.org/10.23865/jased.v3.1283 59 


\section{A. Rønningen}

necessarily have the skills required for this, even though their level of education is high. Thus, there is a possible gap between the competence and skills available and the tasks needed to be done. In the article's last and more exploratory part, explanations are proposed as to why this situation occurred and how it can be solved.

Keywords: School of Music and Performing arts; leadership in Schools of Music and Performing arts; curriculum framework for School of Music and Performing arts; competency situation in School of Music and Performing arts; Policy in School of Music and Performing arts

Received: June, 2018; Accepted: May, 2019; September, 2019

\section{Innledning}

Er kulturskolene i stand til å utføre de oppgavene de er satt til? Er kompetansen hos de ansatte i tråd med det oppdraget de har fått?

Med kulturskolens nye rammeplan Mangfold og fordypning (Norsk kulturskoleråd, 2016) kom det nye veiledende krav og føringer for hva kulturskolen skal være og gjøre. Et slikt nytt planverk kan gi grunnlag for å reflektere over eventuelle behov for endringer i tilbud og organisering, og følgelig også hvordan kompetansen i kulturskolene er innrettet for å møte dette. Selv om rammeplanen for kulturskolen ikke er juridisk forpliktende, setter den veiledende krav og legger føringer for kulturskolene. Rektorene er de som planlegger kompetansen for sin institusjon, og er ansvarlige overfor skoleeier for at kulturskolens stab leverer i tråd med det som forventes. Denne artikkelen tar utgangspunkt i hvordan kulturskolerektorene i tre fylker (Buskerud, Telemark og Vestfold) forstår kompetansesituasjonen i egen kulturskole i lys av rammeplanen, og foreslår deretter mulige forklaringer på dette.

\section{Bakgrunn}

Prosjektet som denne artikkelen omhandler ble igangsatt av styret i Norsk kulturskoleråd region BTV (Buskerud, Vestfold og Telemark) fordi det i en gryende dialog mellom kulturskolefeltet og den regionale høgskolesektoren ble synlig et behov for mer forskningsbasert kunnskap. Det eksisterte ingen felles forståelse i kulturskolefeltet over hvilke kompetanser som eventuelt manglet i dagens kulturskolestab, og hvilke kompetanser som feltet kunne ha bruk for mer av i framtiden. Det ble erfart at uten en bedre oversikt over hva som finnes av formell og reell kompetanse blant de ansatte, og omkring ledernes vurdering av denne, så var det vanskelig å vite hva kulturskolefeltet kan be om hos utdanningstilbyderne. Det var også en usikkerhet om det finnes et misforhold mellom den formelle kompetansen som allerede tilbys gjennom utdanningssystemet og den reelle kompetansen det er behov for i praksisfeltet. På dette grunnlaget bestilte styret i Norsk kulturskoleråd BTV en surveyundersøkelse, og som en fortsettelse av dette ble det arrangert et dialogseminar. 
Det empiriske grunnlaget til denne artikkelen er hentet fra surveyen som ble giort blant de $45^{1}$ kulturskolene i BTV i 2016, og gjennom tekster og notater fra gruppearbeid samt forskerens egne refleksjonsnotater etter deltagende observasjon i den påfølgende dialogkonferansen for kulturskolefeltet og Universitets- og høgskolesektoren (heretter UH-sektoren) der surveyresultatene ble presentert. Resultatene fra surveyen er publisert i en egen rapport (Rønningen, 2018), men tolkes i denne artikkelen i lys av kvalitative data fra dialogseminaret, og settes i forbindelse med annen forskningsbasert kunnskap på feltet.

\section{Forskningsspørsmål}

Artikkelen stiller følgende forskningsspørsmål: Hvordan tolker kulturskolerektorer $i$ Buskerud, Telemark og Vestfold (BTV) kompetansesituasjonen $i$ sine institusjoner $i$ relasjon til rammeplanens krav og intensjoner? Data fra dette første spørsmålet føres videre og danner grunnlaget for en mer eksplorerende og essayistisk form mot slutten av artikkelen der følgende spørsmål belyses: Hva er mulige forklaringer på et udekket kompetansebehov?

\section{Rammeplanen og kompetanse: kunnskap, utvikling og tidligere forskning}

Dette underkapitlet undersøker kompetansebegrepet i relasjon til rammeplanen og tidligere forskning.

\section{Kort om kompetanse}

Det kan være hensiktsmessig å se på antikkens begreper om kunnskaps- og ferdighetsformer for å forstå hva kompetanse i kulturskolen kan være. Episteme forstås som teoretisk, erkjennelsesbasert kunnskap; Technè har med håndverksmessig praktisk utøvelse av ferdigheter å gjøre; Fronesis, et begrep særlig knyttet til Aristoteles, kan forstås som en holdning der relasjonelle ferdigheter og evner til å gjøre gode praktiske vurderinger i forskjellige kontekster settes i spill (Gustavsson, 2000). Hva som menes med kompetanse i skolen kan belyses ved en definisjon fra en offentlig utredning fra 2015. Der forutsettes alle disse tre overnevnte dimensjonene, men man kan se at elementer fra fronesis er spesielt viktige:

\footnotetext{
Kompetanse betyr å kunne mestre utfordringer og løse oppgaver i ulike sammenhenger og omfatter både kognitiv, praktisk, sosial og emosjonell læring og utvikling, inkludert holdninger, verdier og etiske vurderinger. Kunnskaper, ferdigheter, holdninger og etiske vurderinger er alle forutsetninger for og deler av det å utvikle kompetanse. (NOU 2015:8, s. 19)
}

\footnotetext{
${ }^{1}$ Antall kulturskoler har siden undersøkelsene ble gjort endret seg grunnet kommunesammenslåinger og omorganiseringer.
} 


\section{A. Rønningen}

I denne artikkelen henvises det til henholdsvis formell kompetanse og realkompetanse. Formalkompetanse er sertifisert kompetanse, ervervet gjennom utdanning og dokumentert gjennom vitnemål; realkompetanse handler om faktiske kunnskaper, ferdigheter, holdninger, etiske vurderinger og evne til å anvende dette i sin arbeidssituasjon.

\section{Rammeplanen og formell kompetanse}

Kulturskolens rammeplan fra 2016 innebærer flere endringer og justeringer i forhold til tidligere planer. For det første gir rammeplanen av 2016 for første gang klare (veiledende) krav til formell kompetanse:

For tilsetting i undervisningsstilling skal det normalt kreves: Høyere kunstfaglig utdanning i utøvende og/eller skapende kunstfag, tilpasset undervisningsoppgavene for stillingen. Som minimum kreves tre års kunstfaglig utdanning. Krav om praktisk pedagogisk utdanning gjelder alle. Alternativt: Faglærerutdanning med minimum 120 studiepoeng kunstfag.

Skoleeier kan i særlige tilfeller tilsette søkere som ikke tilfredsstiller disse kravene dersom tilsvarende realkompetanse kan dokumenteres. (Norsk kulturskoleråd, 2016, s. 16-17)

Det finnes lite forskningsbasert kunnskap om hva slags formell kompetanse som finnes i kulturskolen. I rapporten "Kulturskoleløftet - Kulturskole for alle» (Kulturskoleutvalget, 2010a) beskrives kulturskolelærernes formelle kompetanse som høy. Waagen skriver at $186,4 \%$ av lærerne i kulturskolene har høyere kunstfaglig utdanning, de resterende har høy realkompetanse» (Waagen, 2016, s. 228). Det er imidlertid uklart hvor dette tallet kommer fra $^{2}$, og hva som ligger i betegnelsene «høyere kunstfaglig utdanning» og "høy realkompetanse».

\section{Rammeplanen og realkompetanse}

Rammeplanen gir gjennom sin inndeling i tre programmer - breddeprogram, kjerneprogram og fordypningsprogram - og sitt fokus på kulturskolen som ressurssenter (Norsk kulturskoleråd, 2016, s. 8-12), noen mulige forordningsprinsipper å sortere og diskutere kulturskolenes kompetansebehov etter. Det kan handle om forskjellige kompetanser som er innrettet på å fylle forskjellige behov relatert til de forskjellige programmene og oppgavene som kulturskolen har.

I praksisfeltet har det vært et fokus på kulturskolelæreres kompetanse, særlig gjennom Norsk kulturskoleråds arbeid nasjonalt og regionalt, med kurstilbud og aktivitetstilbud for fagpedagoger, som for eksempel Pedagogdagene, som ble gjennomført i

${ }^{2}$ Waagen oppgir «Kulturskoleløftet - kulturskole for alle» som kilde, men denne rapporten inneholder ikke denne informasjonen. Imidlertid finnes en kartlegging $\mathrm{i}$ en av de bakenforliggende arbeidene for kulturskoleløftet. Av Kulturskoleutvalget (2010b) kan man utlede at prosentandelen kulturskolelærere med mastergrad, bachelorgrad eller annen relevant utdanning utgjør om lag $86 \%$. 
2012, 2015 og $2016^{3}$, gjennom nasjonale og regionale Kulturskoledager ${ }^{4}$ som fokuserer på kompetansebygging hos pedagoger og rektorer, og gjennom regionalt og lokalt organiserte fagdager. I oktober 2015 startet en omfattende høringsprosess for nye nasjonale fagplaner. Gjennom de første fasene ${ }^{5}$ som foregikk mellom oktober 2015 og april 2016, ble kompetanse og profesjonsforståelse diskutert i mange kulturskoler. Det var i dette arbeidet et stort fokus på å legge til rette for en sterkere delingskultur for å kunne bygge profesjonelle læringsfelleskap i kulturskolekollegiene (Rønning, Rønningen \& Westby, 2017).

\section{Bredde og dybde-diskurser}

Med utgangspunkt i den nasjonale fagplanen for musikk for kulturskolen identifiserer Ellefsen (2017) flere kunnskapsdiskurser som kan ha stor relevans for forståelsen av hva slags kompetanse som trengs i kulturskolen. Jeg finner diskursparet dannelse/ musikalsk kompetanse spesielt relevant for denne artikkelen. Ellefsen knytter dannelse spesielt til breddeprogrammet, og skriver på bakgrunn av sin lesning av rammeplanen at det er en viss fare for at

... breddeprogrammet, med sine dannelsesmål og underutviklede musikalske ferdighetsmål, kan komme til å fremstå som et sideprosjekt til kjerneprogrammet, i gråsonen mellom kulturskole og annet lokalt kulturliv, og mellom musikalsk læring og sosial fritidsaktivitet. (Ellefsen, 2017, s. 9)

Her sies det at breddediskursen mangler tydelighet i rammeplanen, og dette har betydning for hvordan man kan tolke et eventuelt kompetansebehov i dette området.

Jordhus-Liers ph.d.-avhandling (2018) undersøker identitet og profesjonsforståelse hos kulturskolelærere i musikk, og hun identifiserer flere institusjons- og lærerdiskurser som kjemper om å definere feltet. I sitt materiale som er hentet fra intervjuer med lærere, finner Jordhus-Lier en konflikt mellom en dominant bredde-diskurs i institusjonen (i policydokumenter og lignende)og en lærerdiskurs som vektlegger spesialisering.

I binariteten bredde-dybde er breddediskursen identifisert som den mest dominerende i datamaterialet. Dette er artikulert gjennom ideen om at kulturskolen har et bredt mandat der alle barn skal bli inkludert og at den har et ansvar for kunst og kulturutdanning generelt. Dybdediskursen er også tilstede, hvor betegnerne 'individualisme' - at alle barn skal ha mulighet til å velge hvilke aktiviteter de vil delta på - og 'kvalitet' - som er sikret gjennom spesialisering og dybde - er de mest sentrale. Videre har analysen vist at mens breddediskursen er dominerende i de offentlige dokumentene, er spesialiseringsdiskursen dominerende i intervjumaterialet. Dette skaper spenning. (Jordhus-Lier, 2018, s. X)

${ }^{3}$ https://www.kulturskoleradet.no/vi-tilbyr/arrangement/pedagogdagene.

${ }^{4}$ https://www.kulturskoleradet.no/vi-tilbyr/arrangement/kulturskoledagene.

${ }^{5}$ Høringsprosessen besto av tre faser, hvor de to første fasene la vekt på aksjonslæring og utprøving. Se https://www.kulturskoleradet.no/nyheter/2016/januar/rammeplanens-fagplaner-er-horingsklare 


\section{A. Rønningen}

Lignende motstridende diskurser identifiseres på ledernivå i kulturskolen i Sverige av Di Lorenzo Tillborg (2017), som gjennom fokusgruppesamtaler med kulturskolerektorer i Sverige identifiserer spenningsfelt i diskusjoner om kulturskoledeltakelse som henholdsvis fritidssyssel eller tradisjonell fagspesialisering, om klassiske og ikkeklassiske tilnærminger og innholdsvalg, og om bred elevtilpasning eller skreddersøm til talenter.

Jeg har i en tidligere artikkel sett på kulturskolens rammeplan i lys av community music teori, og hevder at det finnes gode muligheter for å forstå særlig kulturskolens breddeprogram gjennom å sammenlikne det med begrunnelser og ideologi i community music-feltet (Rønningen, 2017). Jeg viser hvordan sentrale elementer fra community music-feltet, som lavterskel deltagelse for alle (access and participation), vekt på sosiale faktorer og meningsfullhet (social aspects) og fleksible rammer for organisering i tråd med brukernes behov og ønsker (frames and flexibility), langt på vei korresponderer med kulturskolens visjon om å være "for alle» (Norsk kulturskoleråd, 2016, forord), om å være et ressurssenter (Norsk kulturskoleråd, 2016, s. 8), og om at breddeprogrammet fokuserer på deltagelse og meningsfullhet.

Aglen og Karlsen (2017) har kartlagt utdanningsveier til kulturskolelæreryrket for musikk, og ser på hva slags kompetanser de forskjellige utdanningsløpene kan føre til. De drøfter også forholdet mellom bredde og dybde i utdanningene, og mener utdanninger for breddeprogrammet til kulturskolen må sørge for «... svært høy kommunikativ kompetanse samt relasjons- og lederkompetanse» (Aglen \& Karlsen, 2017, s. 173).

Noen nyere arbeider fra Norge reflekterer over dette forholdet mellom kulturskolens praksisfelt og utdanningene som skal forsyne feltet med kompetanse for fremtiden. Westby (2017a, 2017b) og Brøske (2017) har forskjellige innganger til - og refleksjoner over - sammenhengen mellom praksisfeltet og utdannelse til dette, især hva gjelder samarbeid kulturskole og grunnskole. Angelo (2012) har i sin ph.d.-avhandling, og i flere arbeider siden (2014, 2015, 2016a, 2016b) sett på profesjonsforståelser hos instrumentallærere i kulturskolen. Antologien Kunstner eller Larer (Angelo \& Kalsnes, 2014) har også flere bidrag fra forskjellige forfattere som drøfter profesjon, identitet og kompetanse for kulturskolelærere, med subjektposisjonene kunstner og/eller lærer som omdreiningspunkt, og drøfter med det to mulig kontrasterende kompetansediskurser hos lærerne. Waagen (2011) omtaler kompetansesituasjonen i mer generelle vendinger, og i et senere essay tolker hun spesifikk kompetanse hos instrumentallærere i kulturskolen (Waagen, 2016). Sentralt i disse arbeidene er at forfatterne viser at kulturskolelæreren må ha allsidig kompetanse både som utøver og pedagog.

Idet kulturskolefeltet i Skandinavia har store likheter, kan også forskningsarbeider fra Danmark være relevante å kjenne til for å forstå kompetansesituasjonen i Norge. Holsts (2013) behandler kompetanse hos musikklærere blant annet i den danske kulturskolen fra et mer overordnet perspektiv, og han viser hvordan det eksisterer to kompetansediskurser for musikklærere, og at disse regenereres giennom separate kretsløp. Gitt at situasjonen i Norge er lik den danske kan vi anta at det også i Norge 
er slik at musikkonservatorienes mesterlæretradisjoner føres videre inn i kulturskolen der de konservatorieutdannede lærerne underviser, og at den mer allmennpedagogiske musikklærerdiskursen gjenskapes gjennom grunnskolen og lærerutdanningene. Slike undervisningskulturer er konservative og tar tid å endre.

Også noen svenske studier kan være relevante for å forstå diskursive spenninger mellom bredde- og dybde knyttet til organisasjonenes ideologi. Kunnskapsdiskursene er førende i forståelsen av institusjonens oppdrag og dermed relevante for å drøfte hvorvidt kompetansen i organisasjonene er innrettet for å utføre dette. Både Hofvander Trulssons avhandling (2010) som undersøker musikkens betydning i et klasseperspektiv, og dermed anskueliggjør behovet for bredde- og mangfoldskompetanse i kulturskolen, og Holmbergs avhandling fra samme år viser motstridende diskurser mellom bredde og dybde, som fordrer forskjellige kompetanser (Holmberg, 2010). I Sverige har også kulturskoleutredningen gitt insentiver til drøfting av hva kulturskolen skal være og følgelig hva slags kompetanse som det er behov for (Kulturdepartementet, 2016).

\section{Metodologi og forskningsdesign}

Dette prosjektet er tett knyttet sammen med utviklingsprosesser i praksisfeltet. Det har derfor vært ønskelig å ha en åpen og bred forskningsmetodisk inngang som kan fange opp praksisfeltets egne forståelser og utfordringer, og både gi valide forskningsdata og foreslå mulige tolkninger som kan fungere som insentiver til endring.

Arbeidet med denne artikkelen skaper, og forholder seg til forskjellige forskningsdata så vel som metoder fra forskjellige tradisjoner. Inspirert av Alvesson og Sköldbergs refleksive metodologi er det brukt en kombinasjon av empirinære - «tolkningsfattige» - metoder; mer tolkningsrike, hermeneutiske tilnærmingsmåter; kritisk fortolkende diskursrelevante innganger samt dels også en bevissthet og selvkritisk holdning til språk og forskerposisjon (Alvesson \& Sköldberg, 2008, s. 491).

Følgende figur illustrerer de forskjellige datatilgangene og metodisk tenkning.

empirisk materiale

metodisk tilnærming

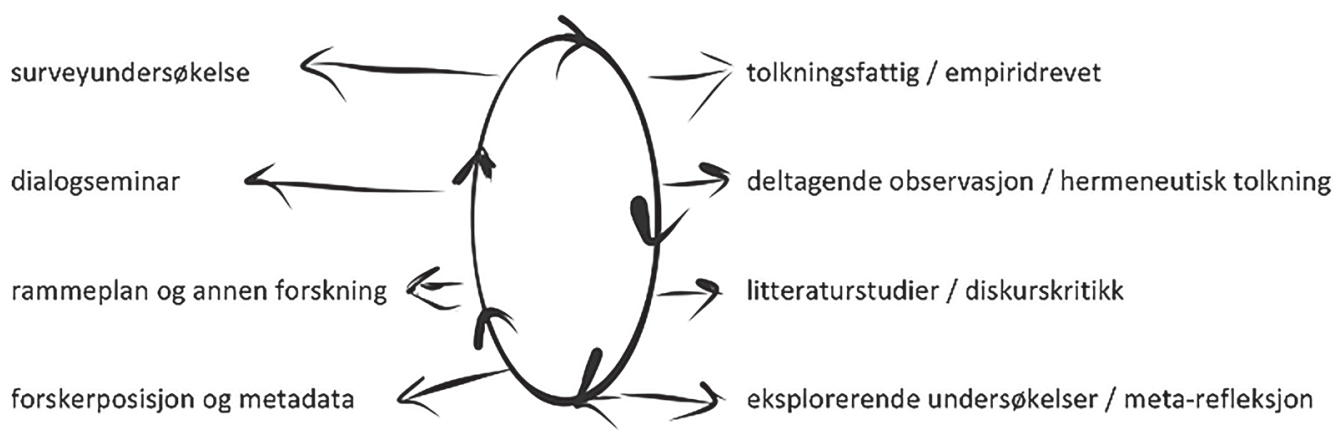

Figur 1. Metodisk tilnærming og empiriske data. Design: Anders Rønningen. 


\section{A. Rønningen}

Forbindelsene mellom empiriske data og metodisk tilnærming er markert som en toveis pil for å anskueliggiøre at det ikke en enveis kausal forbindelse mellom empiriske data og metodiske innganger. Det er også piler som forbinder alle empiriske elementene med alle metodiske tilnærmingene, og dette er for å indikere at alle datatilfang i prinsippet kan behandles gjennom alle metodiske tilgangene, og i en kompleks virkelighet også er tett flettet inn i hverandre. I denne artikkelen er de heller ikke adskilt gjennom separate avsnitt i kronologisk rekkefølge, men starter i det tredje elementet ved å forholde seg til rammeplanen og tolke forskning på kulturskole og kompetanse (fordi det skaper nødvendige bakgrunnsforståelser for leseren), hvoretter det første elementet er fremtredende (gjennom presentasjonen av survey-resultater). Dernest kommer gradvis mer fra det andre elementet (fortolkende tilnærminger, med empiri fra dialogseminaret), og til slutt - i en mer eksplorerende del noe sterkere innslag av element 4 . Det ikke noe gitt forhold mellom de forskjellige elementene, men den gjennomgående refleksjonen skaper forbindelse mellom disse elementene og fungerer som forbindelseslinjer - «pipelines» - mellom metodiske paradigmer som ellers regnes som uforenlige (Alvesson \& Sköldberg, 2008, s. 542).

\section{Prosjektets fire empiriske og metodiske elementer}

I figur 1 er prosjektets metodiske tilnærming delt inn i fire elementer som hver forholder seg til empiriske data.

Det første elementet er en survey som ble sendt til alle kulturskolerektorene i Buskerud, Vestfold og Telemark. Surveyen etterspør informasjon om formell kompetanse og realkompetanse hos kulturskolelærerne og rektorenes refleksjoner over kompetansebehov i sin kulturskole for fremtiden. Undersøkelsen ble administrert over plattformen Surveymonkey. For å sikre en størst mulig oppslutning om undersøkelsen og en effektiv innhenting av informasjon, ble undersøkelsen forberedt og temaet for surveyen drøftet på flere nettverkssamlinger for rektorer i forkant. ${ }^{6}$ Rektorene har dermed også selv vært med på å legge føringer for utforming av spørsmålene, og således er kategoriseringer og spørsmålsstillinger dels sprunget ut av praksisfeltet selv (og dette vil dermed høre til element nummer to). Styret i Norsk kulturskoleråd BTV hadde også en gjennomgang av spørsmålene, og det ble sendt ut test-oppgaver til to rektorer og tre representanter fra utdanningssektoren. Noen av spørsmålene i surveyen var overlappende med offentlig tilgjengelig statistikk, ${ }^{7}$ og noen av resultatene kunne dermed sjekkes mot dette. Resultatene ble sammenfattet og presentert muntlig i flere kulturskolefora (blant annet dialogkonferansen beskrevet nedenfor), og er senere utgitt som kortfattet rapport uten videre tolkninger (Rønningen, 2018).

${ }^{6}$ Rektorene møtes fire-fem ganger $\mathrm{i}$ året $\mathrm{i}$ fylkes- eller regionvise nettverksamlinger som er ledet av en regional rådgiver fra Norsk kulturskoleråd.

${ }^{7}$ for eksempel det som finnes i grunnskolens informasjonssystem (https://gsi.udir.no/). 
Det andre elementet handler i større grad om tolkning. Dette korresponderer først og fremst med fase to i prosjektet som både kollektivt tolket resultatene fra surveyundersøkelsen, og hentet inn mer kvalitative data i form av refleksjoner fra rektorene. Konkret bestod dette av å presentere de preliminære surveyresultatene for rektorene og utdanningssektoren på en dialogkonferanse ${ }^{8}$, der formålet også var å starte en dialog om kompetanse i kulturskolen. På seminaret deltok 20 av de 45 rektorene i BTV, og om lag like mange representanter og interesserte fra UH-sektoren regionalt og nasjonalt. Ved å presentere konkrete tall og innspill fra surveyen på dette seminaret, og også gi tid til kollektive refleksjoner og gruppearbeid er reaksjonene på presentasjonen av det statistiske materialet også inkludert som et tolkningsgrunnlag for denne artikkelen. Som deltagende observatør i dialogseminaret og som rådgivende aktør i praksisfeltet fikk jeg som forsker også et inntrykk av mangfoldet av synspunkt på kompetansesituasjonen. Denne delen av datainnhentingen er nærmere en kvalitativ metode, og er tett sammenvevd med et styrt utviklingsarbeid i kulturskolesektoren. På bakgrunn av de data som var kommet inn gjennom surveyen kunne kulturskolefeltet og utdanningsfeltet selv ta tak i (kompetanse) utfordringer som var identifisert, og nå hadde konkrete data for å reflektere over behov i sine praksisfelt. Som metode har det å legge til rette for slike refleksjoner for praksisutvikling noe til felles med praktisk aksjonsforskning (Carr \& Kemmis, 1986). Empirien som var innsamlet giennom surveyen ble slik ikke bare tolket av forskere, men også i det profesjonsfelleskapet som den var hentet fra. Refleksjonen blir satt $\mathrm{i}$ omløp, ved at den synliggiør praktiske utfordringer i feltet. Den viser mulige veier å gå for å legge til rette for økt dialog og samarbeid. På dialogkonferansen ble det også presentert annen relevant forskning og innspill fra forskjellige representanter fra UH-sektoren. Datainnsamlingen ble foretatt ved at det ved arbeid i grupper bestående av både rektorer fra kulturskolen og representanter fra UH-sektor ble laget oppsummerende notater som ble sendt til meg i etterkant. Gruppearbeidet ble også presentert i plenum, og arbeidsformen kan med det kalles en tilpasset ITP-metode (Individuell - Team - Plenum), slik den er presentert blant annet hos Bjørnsrud (2015).

Det tredje elementet er i dette prosjektet en mer diskurskritisk behandling av materialet fra første og andre fase, der datamaterialet er sett i sammenheng med diskursive kategorier som er utledet fra dokumentanalyser av rammeplanen og annen forskning på rammeplan og profesjon. Særlig har jeg her brukt Jordhus-Lier (2018), Ellefsen (2017) og egne tidligere arbeider (Rønningen 2017, 2018). Dette elementet tar utgangspunkt i rammeplan for kulturskolen (Norsk kulturskoleråd, 2016), i en rapport fra fagplanpilotarbeidet (Rønning, Rønningen \& Westby, 2017), og

\footnotetext{
${ }^{8}$ Arrangementet ble kalt dialogkonferanse, og denne dialogkonferansen hadde mange fellestrekk med den som er beskrevet av for eksempel Lund, Rotvold, Skrøvset, Stjernestrøm \& Tiller (2010), og som kan ses som et verktøy i aksjonsforskning, men forholdt seg friere i forhold til organisering og struktur.
} 


\section{A. Rønningen}

forsøker ut i fra dette å finne diskurser som er relevante kontraster i materialet. Det er også andre diskursanalytiske innganger til dette, blant annet hos Angelo og Karlsnes (2014), som har gitt tolkningskategorier som kan belyse rektorenes vurdering av kompetansesituasjonen.

Det fjerde elementet - dekonstruksjon og metatenkning - utgjør ingen adskillelig del av resten av forskningsprosjektet, men øves kontinuerlig gjennom prosjektet. Det handler om refleksjon og problematisering av min egen rolle som forsker og samtidig rådgiver og deltagende observatør. Med flere roller i prosjektet, både som rådgiver, kartlegger, deltagende observatør og forsker er denne refleksjonen viktig å klargjøre her for denne artikkelens del, men også ikke minst underveis, overfor forskningsdeltagerne. Kompetansekartlegging var en viktig del av bakteppet for prosjektet som ble startet fordi Norsk kulturskoleråd BTV ønsket økt samhandling mellom kulturskolesektoren og UH-sektoren, og det var behov for å kartlegge hvordan kulturskolesektoren (v/rektorene) tenkte om kompetanse i sine skoler. Ønsket om å få mer kunnskap om dette var derfor en bestilling som la føringer på meg både som rådgiver og forsker, men den doble rollen ble også en viktig forutsetning både for tolkning, forståelse og bidrag inn i en utviklingsprosess der kulturskolesektoren og UH-sektoren skulle nærme seg hverandre.

Som forsker tilhører jeg flere tolkningsfelleskap, og det er ikke hverken ønskelig eller mulig å fravriste seg disse, og det gjør det derfor viktig å påminne både meg selv og leseren om viktigheten av refleksivitet. Alvesson og Skôldberg skriver om empirisk forskning preget av refleksjon, at det utgår fra en

... skepsis mot vad som vid en ytlig anblick framstår som oproblematiska avspeglingar av hur verkligheten fungerar, samtidigt som man vidmakthåller tron på at studiet av lämpliga (genomtänkta) utsnitt av denna verklighet kan ge viktigt underlag till en kunskapsbildning som öppnar snarare än slutar, som ger möjligheter till förståelse snarare än fastställer «sanningar». (Alvesson \& Sköldberg, 2008, s. 20)

Under dette fjerde elementet er det naturlig å dekonstruere sentrale begreper (som for eksempel kompetanse), og - sammen med praksisfeltet - problematisere begrepers beskaffenhet gjennom å se på ideologiske bindinger og tatt-for-gitt-heter i diskursene. Denne inngangen er av plasshensyn lite utviklet i denne artikkelen, men har vært brukt i praksisutviklings-øyemed ved for eksempel å diskutere hva kunnskap er. En dekonstruksjon av begrepet «kunnskap» med utgangspunkt i rektorenes forståelse slik den kommer til uttrykk i dette prosjektet, er naturlig å forske videre på, og vil søkes utviklet senere.

\section{Så hva tenker rektorene om kompetansebehovet i kulturskolen?}

Dette underkapittelet tar for seg rektorenes tanker om kompetanse og kompetansebehov i kulturskolen. 
Surveyundersøkelsen og dialogseminaret

Surveyundersøkelsen gir først og fremst et bilde på formelt utdanningsnivå blant kulturskolelærerne. Det forelå en forforståelse om at grad av formell fagrelevant utdanning og formell pedagogisk utdanning varierte i forhold til stillingsstørrelse, og det var en antagelse om at de med høyest stillingsprosent hadde høyest formell utdanning. Datagrunnlaget i surveyen styrker denne antagelsen (Rønningen, 2018). Av de som er ansatt i stillinger på over $55 \%$ har ca $78 \%$ kunstfaglig utdannelse på tre år eller mer. Bildet er noe annerledes dersom man ser på formell pedagogisk utdanning, der gruppen av lærere med middels stillingsprosenter (25-55\% stilling) scoret høyest (87,7 \% har pedagogisk utdanning), de med lave stillingsprosenter var signifikant lavere $(57,7 \%$ har pedagogisk utdanning), mens det blant de med høyest stillingsprosent var 73,5 \% med pedagogisk utdanning. Det kan være mange grunner til denne fordelingen, men datamaterialet gir ikke grunnlag for videre spekulasjoner. Viktigst er det at surveyundersøkelsen viser at det er høy formell kompetanse $i$ kulturskolelcererkollegiet, både fagkompetanse og pedagogisk, og at denne kompetansen er høyere for de som er ansatt i større stillinger. For å tilfredsstille rammeplanens formelle kvalifikasjonskrav må man ha minst tre års høyere kunstfagsutdanning og PPU, eller minst treårig faglærerutdanning i det relevante kunstfaget. Man kan på bakgrunn av tallene fra surveyrapporten si at vel $70 \%$ av kulturskolepedagogene i BTV fyller de pedagogiske kvalifikasjonskravene (minst et år), mens cirka $60 \%$ har treårig høyere kunstfagutdanning. For de med høy stillingsprosent (over $55 \%$ ) er tallet hele $80 \%$. Satt opp mot utdanningsgraden for lærere i musikk i grunnskolen, der bare $8 \%$ har mer enn ett år med musikkutdannelse (Lagerstrøm, Moafi \& Revold, 2014), er dette et høyt tall.

Men selv om vi kan gå ut i fra at et høyt formelt utdanningsnivå sannsynliggjør et høyt operasjonelt nivå hos profesjonsutøveren, er det ikke nødvendigvis slik at disse utdanningene fører til at kulturskolene får det tilfang av kompetanser som institusjonen har behov for. Dette ble videre undersøkt gjennom flere fritekstoppgaver $\mathrm{i}$ surveyen og videre drøftet og belyst på dialogseminaret.

\section{Hva slags kompetanser er det behov for?}

På surveyens spørsmål «På hvilke områder trengs det mer/annen formell kompetanse for å kunne realisere dine visjoner for kulturskolen i tiden framover?» kom 32 svar i fritekst. En nærlesning og analyse av disse svarene viser for det første at ordet gruppeundervisning opptrer i 14 av de 32 svarene. Det kan være en indikasjon på at den breddediskursen som Jordhus-Lier (2018) finner sterkest til stede i institusjonen (og ikke i kollegiet der spesialiseringsdiskursen har hegemoni) ikke har den nødvendige kompetansedekningen i følge rektorene. I syv svar (av 32) er det eksplisitt referert til ordet klasseromsdidaktikk, noe som også må tilskrives en bredde-diskurs der gruppeundervisning og breddeprogramstilbud (jf. rammeplanen) er rådende. 


\section{A. Rønningen}

Spørsmålsstillingen i surveyen ble gjort uten at det på forhånd ble gitt svaralternativer eller eksempler som kunne styre rektorenes svar, og svarene er dermed også en indikasjon på hva rektorene definerer som kompetanser, og hvilke kategorier de selv benytter. Svarene reflekterer altså det rektorene er opptatt av og ikke nødvendigvis den faktiske situasjonen. Det er likevel plausibelt å hevde at de kompetansene rektorene oftest savner er knyttet opp til deres vurderinger som profesjonelle ledere, og dermed tilsvarer et reelt behov for å imøtekomme krav og intensjoner i rammeplanen.

I dialogseminaret ble det mulighet til å ta svarene fra surveyen videre både for å undersøke troverdigheten i de preliminære tolkningene og å drøfte problematikken noe dypere i rektorkollegiet. Et av spørsmålene i surveyen handlet om hvilke kompetanser kulturskolen trenger mer av for å realisere intensjonene i rammeplanen. I og med at den nye rammeplanen setter mer detaljerte krav til undervisningen giennom at den ordnes inn under tre programmer, ble det lagt opp til svar i fri tekst, ordnet under kategoriene for breddeprogrammet, for kjerneprogrammet og for fordypningsprogrammet. Det ble her ikke spurt etter formalkompetanse, og spørsmålet gir med det grunnlag for å kunne belyse hvor det største behovet for realkompetanse finnes.

Under rubrikkene for fordypningsprogrammet og for kjerneprogrammet rapporteres det at det i stor grad er tilstrekkelig kompetanse. De fleste svarer at de er godt dekket, og at det finnes nok kompetanse regionalt til å samarbeide om talentarbeid og liknende (Rønningen, 2018).

Under rubrikken for grunnprogrammet svarte derimot hele $80 \%$ av respondentene at det var behov for mer kompetanse, og at dette var innen gruppeundervisning, klasseledelse, breddekompetanse og tverrfaglig kompetanse. På et konkret spørsmål om hva rektorene etterlyser av innhold i kurs og videreutdanninger underbygges dette funnet, idet $73 \%$ av respondentene her svarer at det bør ha med å øke pedagogisk kompetanse omkring varierte undervisningsmetoder og særlig gruppeundervisning å gjøre. Det er dermed grunnlag for å si at det er kompetanser som kan regnes som viktige innenfor en breddediskurs som etterlyses, og dette korresponderer med føringene i rammeplanen, som i større grad enn før prioriterer sosiale dimensjoner og samfunnsaspekt.

\section{Er det et misforhold mellom kompetansen som finnes og den som behøves for fremtiden?}

Surveyundersøkelsen (Rønningen, 2018) viste at det er forholdsvis høy formell kompetanse blant kulturskolelærere. Spørsmålet er da hvorvidt rektorene mener den formelle kompetansen er riktig innrettet til de praktiske oppgavene kulturskolen er satt til å løse, og om den er relevant for de kunnskapsbehovene som kulturskolen har etter rammeplanen. Fritekstsvarene i surveyoppgaven målbærer mye av den meningsbrytningen som også kom frem under dialogseminaret. Noen av utsagnene setter 
ord på situasjoner der begrepene kompetanse og til dels også utdanning tolkes som å stå i veien for hva rektorene mener skolene har behov for. Dette må tolkes som en mistillit til utdanningssystemets sertifisering, og mer presist som at det for disse informantene ikke er samsvar mellom innholdet i den formelle kompetansen som finnes og de kompetansebehovene som kulturskolene har. En av rektorene sier sågar at manglende formell pedagogisk kompetanse gjennomgående er sammenfallende med høyere pedagogisk kvalitet (Rønningen, 2018). Under dialogseminaret ble det tydelig at dette ikke var kun én rektors mening.

En annen informant mener at de pedagogene med den formelle kompetansen i orden, er lite motivert for endring, og at de dermed ikke kan fylle kompetansebehovet som følger av rammeplanens føringer, der det er mer vekt på gruppeundervisning og sosiale aspekter ved kulturskolens breddeprogram. Dette forklares også av en annen rektor til å henge slik sammen at de med høyest spisset faglig-utøvende nivå ikke er interessert $\mathrm{i} a ̊$ undervise på begynnernivå. De er kanskje heller ikke gitt kompetanse på nybegynneropplæring eller opplæring i grupper gjennom sin formelle utdanning. Dette kan gi grunnlag for å hevde at det eksisterer et behov for økt kompetanse innen den (økende) delen av kulturskolevirksomheten som er orientert mot breddediskursen, og at dette aspektet ikke automatisk er dekket gjennom de formelle utdanningsveier som finnes.

\section{«Jeg vet ærlig talt ikke hva som må til for å få de endringene vi ønsker oss»}

Idet denne artikkelen bygger på et arbeid som både springer ut av praksisfeltets egne behov og som har foregått i dialog med praksisfeltet, kan det være fruktbart å tillate en mer eksplorerende tolkning av de empiriske forholdene. Den påfølgende delen av artikkelen gir mulige forklaringer som kan ligge til grunn for hypoteser i videre forskning, skape refleksjon og gi insentiver til utprøving i feltet. En av rektorene skrev følgende i sitt fritekst-svar: «Jeg vet ærlig talt ikke hva som må til for å få de endringene vi ønsker oss» (Rønningen, 2018, s. 13). Rektorenes refleksjoner og øvrig empirisk tilfang gjennom dialogseminaret og kommentert $i$ annen forskning gir mange tolkningsmuligheter. Det er derfor naturlig å gå dypere inn i dette temaet på bakgrunn av rektorenes egne rapporteringer og refleksjoner.

Det er klargjort at rektorene mener det er et kompetansebehov; og surveyundersøkelsen og andre kvalitative data sammenholdt, synliggiør et misforhold mellom formell sertifisering av kulturskolelærerne på den ene siden, og det reelle kompetansebehovet som en del kulturskolerektorer mener å ha for sine institusjoner på den andre. Satt på spissen ville det dermed ikke nødvendigvis utgiøre noen forskjell til det bedre dersom alle de ansatte i kulturskolene hadde komplett formell fagkompetanse og formell pedagogisk kompetanse. Det kan være flere grunner til at det er en slik situasjon, og jeg organiserer drøftingen i det følgende under fem tentative forklaringer på dette, som utforskes kort i lys av undersøkelsen, dialogkonferansen og annen tilgengelig forskningslitteratur. 


\section{A. Rønningen}

\section{Kompetansespriket i kulturskolen kan skyldes et misforhold mellom kulturskolens behov og de typiske utdanningsløpene som fører til kulturskolelærer}

Surveyundersøkelsen viser at rektorene rapporterer om høy fagrelevant utdannelsesgrad på den ene siden, og et konkret kompetansebehov relatert til breddediskursen på den andre siden. Det eksisterer en oppfatning om at utdanningene er konservative $^{9}$, og at mange høyt utdannede kulturskolepedagoger henger fast i mesterlæretradisjonen. Dette kan underbygges hos Holst (2013), som påpeker at det finnes en regenererende sirkularitet i utdanningsløpene. Dette ble også diskutert under dialogseminaret. Hvorvidt det er slik at utdanningsløpene som fører til kulturskolelærer gir for lite utbytte i form av de kompetanser kulturskolene trenger innen breddeopplæringen er det ikke grunnlag for å konkludere med i dette materialet. Men det er godt grunnlag for å fastslå at noen av rektorene mener at dette er tilfelle.

Det finnes ingen entydig og klar profesjonsutdanning for kulturskolen i Norge. Det er vanlig å følge profesjonsløp som kunstfagpedagog (for eksempel musikkpedagog) eller mer utøverrettede utdanninger med praktisk-pedagogisk utdanning (PPU) ${ }^{10}$. Det er mulig å tenke seg at den lærerprofilen som vil passe for kulturskolelærere (f.eks. i musikk) på breddeprogrammet bør «innebære svært høy kommunikativ kompetanse samt relasjons- og lederkompetanse, mens den kunstfaglige kompetansen kanskje ikke behøver å være på ekspertnivå for at undervisningen skal kunne gjennomføres på kompetent vis» (Aglen og Karlsen, 2017, s. 173). Dette samsvarer i alle fall godt med rektorenes ønske om mer bredde, og kompetanse til å arbeide med grupper av barn. Spørsmålet er da om det finnes nok av denne type kompetanse i de vanligste utdanningsløpene for kulturskolelærere. Dette er ikke undersøkt i denne omgang, men en slik undersøkelse ville kunne gi svar på om det faktisk finnes et misforhold mellom de vanligste kulturskolelærerutdanningenes innhold og kompetansebehovet i feltet det utdannes til.

\section{Kompetansebehovet i kulturskolen kan skyldes feil prioriteringer ved ansettelser}

En annen tolkningsmulighet er at denne kompetansen likevel finnes i tilgjengelige utdanningsløp (for eksempel i allmennlærerutdanningene), men at pedagoger med denne utdanningsbakgrunnen ikke prioriteres ved ansettelser. Det kan være at de mer utøver-rettede søkerne til stillinger blir prioritert i ansettelser. En hypotese kan være at utlysningene er uklare, eller at dybde framfor bredde faktisk prioriteres ved ansettelsene. En uformell punkt-undersøkelse på alle stillingsutlysninger i kulturskoleområdet støtter en foreløpig hypotese at det $i k k e$ søkes spesifikt etter den type kompetanse som

\footnotetext{
${ }^{9}$ «Musikkutdanningen i Norge er konservativ og våre lærere er preget av det». Fra fritekstsvar på surveyundersøkelsen (Rønningen, 2018, s.13).

${ }^{10}$ For en oversikt over kulturskolelærerutdanninger innen musikk, se Aglen \& Karlsen, 2017.
} 
rektorene i undersøkelsen mente de manglet. ${ }^{11}$ Kun få av utlysningene etterspurte pedagogiske kvaliteter og bredde, og kravet var kun høyere utdanning innen faget. Videre er det mulig det også eksisterer oppfatninger om at kunstnerisk utøverskap gir høyere status enn sosialpedagogiske evner. Det er derfor en mulig forklaring her at spisskompetanse og utøverkompetanse av de som ansetter rangeres høyere enn breddekompetanse i ansettelser. Dette er også i tråd med Jordhus-Lier sine funn, der hun skriver at det blant pedagogene er en spesialistdiskurs som har hierarki. Hun foreslår også en løsning på dette:

I argue that the term 'specialist' must be understood in a broad sense, including, for example, 'group teaching', 'general music' and 'genre knowledge' as forms of specialisation. This is an understanding that can be found in the medical field, where all doctors specialise in something, and some of them specialise as general practitioners, where a holistic approach is central. (Jordhus-Lier, 2018, s. 198)

\section{Kompetansebehovet i kulturskolen kan skyldes en manglende vilje til å tilføre kompetanse til eksisterende personell gjennom videre/etter-utdanning}

I det en stor del av kulturskolenes økonomi er bundet opp i personalkostnader for faste stillinger med lav turnover ${ }^{12}$, er det naturlig å tenke at kompetansebehovet må dekkes av eksisterende stab hvis endring skal skje innen rimelig tid. ${ }^{13}$ Det kan tenkes flere hindre for at en slik kompetanseendring kan skje. Det er mulig å anta at det er pedagogene selv som kan være en hindring i den av rektorene etterlyste kompetanseforsyningen. Dette kan bunne i en manglende endringsvilje hos pedagogene, som helst ikke vil giøre seg kompetente til å gå inn i nye oppgaver fordi de er mer komfortable med eksisterende oppgaver. Dette er indikert som en forklaring hos flere av respondentene. ${ }^{14}$

Det kan også være manglende økonomiske rammer, eller liten vilje hos lederne til å prioritere de økonomiske ressursene til kompetanseutvikling. De strukturelle og kulturelle forholdene i kulturskolekollegiet kan være et hinder for kompetanseutvikling. Bjørnsrud og Rønningen (2017) mener at det i kulturskolekollegier ofte er en svak delingskultur, og nevner små stillinger, liten fellestid, samt lite tradisjon for teamarbeid mellom lærerne som mulige grunner for det.

\footnotetext{
${ }^{11}$ I mai 2016 ble 42 stillingsutlysninger gjennomgått i en uformell undersøkelse av artikkelforfatteren.

${ }^{12}$ Turnover viser til grad av utskifting eller gjennomtrekk av ansatte. Høy turnover betyr at ansatte skiftes ut ofte. Jeg kjenner ikke til at det er gjort nasjonale undersøkelser som dokumenterer turnovergraden i kulturskolen, men det generelle inntrykket er slik, og mange kommuner skriver også dette i utlysninger.

${ }^{13} \mathrm{Jeg}$ har ikke kunnet finne forskning som gir konkrete tall som dokumenterer at kulturskolen har lavere turnover enn i mange andre institusjoner, men dette er et generelt inntrykk som regnes som et faktum hos rektorene, og ble eksplisitt nevnt i materialet fra dialogkonferansen.

${ }^{14}$ «...lærerne er mer motivert for å undervise de eldste elevene og fordypningsprogrammet enn $\mathrm{i}$ hovedgruppen av elever». Fritekstsvar fra surveyen, sitert i rapporten (Rønningen, 2018, s. 13).
} 


\section{A. Rønningen}

Det kan også være manglende vilje fra skoleeier til å prioritere kompetanseutvikling i kulturskolepersonalet på bekostning av lovpålagt kompetanseheving for grunnskolelærere. Dette kan virke som en logisk prioritering (dog uheldig for kulturskolen) idet de formelle kompetansekravene er langt bedre dekket i kulturskolen enn i grunnskolen, og fordi grunnskolen har juridisk forankrede krav gjennom forskrifter som følges av en tilsynsmyndighet. Etter at kulturskoleansatte kom inn under kompetanse for kvalitetsreformen (Kunnskapsdepartementet, 2015) og kan støttes til videreutdanninger, er det ingen formelle hindre for at kulturskolelærere kan søkes inn under denne reformen. En annen utfordring med dette er at det ikke finnes så mange kurs under kompetanse for kvalitets-porteføljen som er innrettet for kulturskolelæreres kompetansebehov.

\section{Kompetansebehovet i kulturskolen skyldes et misforhold mellom kulturskolens samfunnsoppdrag og kulturskoleansattes ønsker for sin arbeidssituasjon}

Denne antagelsen er beslektet med punktet ovenfor, og tar utgangspunkt i at det ikke er gitt at man kan besette en kulturskole med en stab av ansatte som deler rammeplanens visjoner for hva som er kulturskolens oppgaver. Vi har tidligere sett at en bredde-diskurs har hierarki i institusjonen kulturskole, mens det er en spesialiseringsdiskurs som er rådende blant pedagogene. Med andre ord vil en større vekt på de sosiale aspektene, mer vekt på bredde og på ressurssenterfunksjoner ikke nødvendigvis være ønsket av pedagogene. Enkelte data fra undersøkelsen og dialogseminaret viser at lærere søker mot mer spesialisert undervisning på høyere nivå, og Jordhus-Lier (2018) hevder altså at spesialiseringsdiskursen har hegemoni blant lærerne. Det er heller ikke kontroversielt å hevde at mange kulturskolelærere opprinnelig hadde ønske om først og fremst å være utøver, og siden - for å ha noe å falle tilbake på - opparbeider seg nødvendig formell kompetanse til å undervise i kulturskolen. Det betyr ikke at de ikke kan gjøre en like god jobb og tilføre mye god kompetanse, men det er plausibelt å hevde at de har andre kompetanser som de heller ønsker å ha i omløp. En rektor sier at «noen uttrykker også misnøye med elevgrunnlaget fordi man har kompetanse til å undervise på et høyt nivå» (Rønningen, 2018, s. 13), og dette illustrerer at personalet har andre ønsker for sitt arbeid enn det institusjonen har bruk for. Dette kan være vanskelig å endre, og en rektor tolker det slik:

Hovedproblemet vårt er ikke mangel på kompetanse, men mangel på fleksibilitet og oppdatert kompetanse. Det har vært holdt etterutdanningskurs i gruppeundervisning med jevne mellomrom de siste 15 årene uten at det har ført til at lærerne er mer fortrolige med eller motivert for gruppeundervisning. (Rønningen, 2018, s. 12)

\section{Kompetansebehovet kan skyldes manglende evne til å utnytte komplementær kompetanse i kommunen, og til å samarbeide med, og utveksle kompetanse med, kommunens andre institusjoner og det frivillige kulturliv}

Det er lovfestet at kulturskolen skal organiseres i samarbeid med grunnskolen og det frivillige kulturlivet. Datamaterialet fra surveyundersøkelsen for BTV viste at opp 
mot $20 \%$ av alle kulturskolepedagoger også arbeider i grunnskolen. Brøske skriver om de to kunnskapssystemene som kulturskolen og grunnskolen utgjør, og at det kan være mye å hente i et reelt samarbeid, der kompetanse utveksles begge veier, som i en ekspansiv læringsprosess (Brøske, 2017). Dersom kulturskolene tilbyr sin kunstfaglige spisskompetanse inn i grunnskolen, men uten å gå inn i ekspansive læringsrelasjoner, der man nettopp kan få tilflyt av den kompetansen som mangler i kulturskolen, (altså gruppeundervisning, bredde og klasseromsledelse) blir det et bistandsarbeid, og ikke et kompetanseutvidende samarbeid.

Ved å se både grunnskolelærere og kulturskolelærere som grensekryssere, der begge trer inn i ukjente domener med interesse og nysgjerrighet, vil det kunne legges til rette for ekspansiv læring. Det kan muliggiøre en horisontal arbeidsdeling der motsetninger og spenninger kan omfavnes som avgjørende drivkrefter for utvikling av et allmenndannende og skapende musikkfag. (Brøske, 2017, s. 252)

På et ledelsesnivå vil skoleeier derfor kunne ha mye å hente i å se kulturskolens kompetanse i sammenheng med kommunens øvrige kompetanse. Oppgavene som skal løses handler om de samme barna. Dersom kulturskolen skal bli et ressurssenter bør det være en god arbeidsfordeling og kompetanseutveksling mellom institusjonene og aktørene i kommunen.

\section{Konklusjon og oppsummering}

Denne artikkelen har behandlet hvordan kulturskolerektorer i BTV tolket kompetansesituasjonen i sine institusjoner i relasjon til rammeplanens krav og intensjoner, og gitt mulige forklaringer på den udekkede kompetansen som rektorene innrapporterte. Artikkelen slår fast at det er høy formell kompetanse i kulturskolene i BTV, og at rektorene også mener den reelle kompetansen er forholdsvis høy, men at de mener det er behov for styrket kompetanse innen noen områder. Områdene korresponderer med den delen av kulturskolens oppdrag som det gis økte føringer for i rammeplanen, tidligere formulert som økt vekt på sosiale aspekter i kunst og kulturopplæringen, særlig gjennom breddeprogrammet, og økt vekt på kulturskolen som lokalt ressurssenter. Dette er også i tråd med sentrale verdier innenfor community music (Rønningen, 2017). Disse kompetansene hevdes det at ikke er tilstrekkelig dekket gjennom den formelle utdannelsen som kulturskolelærere innehar.

Det er i denne undersøkelsen ikke gjort anslag av kvantitativ art, altså om hvor stort rektorene mener dette kompetansebehovet er, eller hvor stor del av dagens kulturskolestab som eventuelt trenger kompetanseløft, og hvor mye dette utgiør. Det er heller ikke datagrunnlag for å si noe sikkert om hvordan kompetansegapet kan fylles, selv om jeg har belyst en del faktorer som kan gi bakgrunn for informerte beslutninger om tiltak og utprøvinger. Noen av faktorene som foreslås som forklaringsmodeller er innenfor rektorenes egne handlingsrom eller angår strukturelle forhold i kulturskolen som institusjon, mens andre dreier seg om utdanningsfeltet. Det som det imidlertid kan konkluderes med, er at rektorene mener at det på områdene 


\section{A. Rønningen}

breddekunnskap og gruppedidaktikk og -ledelse, må forsterket kompetanse inn i kulturskolene, især for å kunne realisere intensjonen med breddeprogrammet og ressurssentertankegangen i kulturskolens samfunnsoppdrag. For å få til dette bør det legges til rette for en tettere dialog mellom praksisfeltet og utdanningsfeltet. Bare da kan praksisfeltet forsynes med, og selv dyrke fram de kompetansene de trenger for å utøve sitt samfunnsmandat.

\section{Forfatteromtale}

Anders Rønningen (ph.d.) er førsteamanuensis i musikkpedagogikk ved Univer-sitetet i Sørøst-Norge, og FoU-leder i Norsk kulturskoleråd. Han har i sitt forsknings- og utviklingsarbeid hatt særlig interesse for flerkulturelle problemstillinger og kulturskolerelaterte tema. Rønningen var medredaktør i antologien IRIS-forsk - forskning og utvikling $i$ det kulturskolefeltet, og var redaktør og leder av arbeidet med å lage en kunnskapsoversikt over nordisk forskning på kulturskole (utgitt hos Norsk kulturskoleråd i 2019). Han leder også "KIL-forsk», et nordisk forskningsnettverk som arbeider opp mot kulturskoleutviklingsprosjektet Kulturskolen som Inkluderende kraft i Lokalsamfunnet (KIL). Han er også aktiv utøvende musiker og komponist.

\section{Referanser}

Aglen, G. S., \& Karlsen, S. (2017). «Jeg vil bli kulturskolelærer når jeg blir stor - hva innebærer det?» En undersøkelse av kvalifiseringsveier innenfor musikkfeltet». I E. Angelo, A. Rønningen, \& R. J. Rønning (Red.), Forskning og utvikling i kulturskolefeltet. Den doble regnbuen: IRISforsk (s. 157-184). Oslo: Cappelen Damm Akademisk. https://doi.org/10.23865/noasp.21

Alvesson, M., \& Sköldberg, K. (2008). Tolkning och reflektion: vetenskapsfilosofi och kvalitativ metod. Lund: Studentlitteratur.

Angelo, E. (2012). Profesjonsforståelser $i$ instrumentalpedagogiske praksiser. (Doktorgradsavhandling). Trondheim: NTNU Norges teknisk-naturvitenskapelige universitet.

Angelo, E. (2014). Profesjonsforståelser og kunstpedagogikk. Praksiser i musikkfeltet. Bergen: Fagbokforlaget.

Angelo, E. (2015). The music educator: Bridging performance, community and education-An instrumental teacher's professional understanding. International fournal of Community Music, 8(3), 279-296.

Angelo, E. (2016a). A French horn pedagogue's professional understanding. European fournal of Philosophy in the Arts Education, 1(1), 6-37.

Angelo, E. (2016b). Music educators' expertise and mandate: Who decides, based on what? Action, Criticism E Theory for Music Education, 15(2), 178-203.

Angelo, E., \& Kalsnes, S. (2014). Kunstner eller lerer? Profesjonsdilemmaer i musikk- og kunstpedagogisk utdanning. Oslo: Cappelen Damm Akademisk.

Brøske, B. Å. (2017). Samarbeid mellom kulturskole og grunnskole - ekspansiv læring eller bistandsarbeid? I E. Angelo, A. Rønningen, \& R. J. Rønning (Red.), Forskning og utvikling $i$ kulturskolefeltet. Den doble regnbuen: IRISforsk (s. 235-257). Oslo: Cappelen Damm Akademisk. DOI: https://doi.org/10.23865/noasp.21

Bjørnsrud, H. (2015). Skolebasert kompetanseutvikling for læring og utvikling. I H. Bjørnsrud (Red.), Skolebasert kompetanseutvikling. Organisasjonslcering for delingskultur (s. 23-42). Oslo: Gyldendal Akademisk.

Bjørnsrud, H., \& Rønningen, A. (2017). Forskende partnerskap som grunnlag for fagplanhøring og utviklingsprosesser i kulturskolen - erfaringer når kulturskoler vurderer innhold i den nye læreplanen. I E. Angelo, A. Rønningen, \& R. J. Rønning (Red.), Forskning og utvikling i kulturskolefeltet. Den doble regnbuen: IRISforsk (s. 185-206). Oslo: Cappelen Damm Akademisk. DOI: https://doi.org/10.23865/noasp.21

Carr, W., \& Kemmis, S. (1986). Becoming critical. education, knowledge and action research. London: Falmer Press.

Di Lorenzo Tillborg, A. (2017). Tension fields between discourses: Sweden's Art and Music Schools as constituted within and through their leaders' discursive practice. The Finnish fournal of Music Education, 1(20), 59-76.

Ellefsen, L.W. (2017). Musikalsk kompetanse som «mangfold og fordypning». Kunnskapsdiskurser i Rammeplan for kulturskolen. Information - Nordic fournal of Art and Research, 6(1), 1-19. DOI: https://doi.org/10.7577/ information.v6i1.2542 


\section{Kulturskolens kompetansebehov for ny rammeplan}

Gustavsson, B. (2000). Kunnskapsfilosofi. Tre kunnskapsformer i historisk belysning. Smedjebacken:Wahlström och Widstrand.

Holmberg, K. (2010). Musik- och kulturskolan i senmoderniteten reservat eller marknad? (Doktorgradsavhandling). Malmö: Lund University, Malmø Academy of Music.

Holst, F. (2013). Professionel musiklcererpraksis: Professionsviden og lcererkompetence med scerlig henblik på musikundervisning $i$ grundskole og musikskole samt lcereruddannelse hertil. (Doktorgradsavhandling). Århus: Aarhus Universitet.

Hofvander Trulsson, Y. (2010). Musikaliskt lärande som social rekonstruktion. Musikens och ursprungets betydelse för föräldrar med utländsk bakgrund. (Doktorgradsavhandling). Malmö: Lund University, Malmø Academy of Music.

Jordhus-Lier, A. (2018). Institutionalising versatility, accommodating specialists. A discourse analysis of music teachers' professional identities within the Norwegian municipal school of music and arts. (Doktorgradsavhandling). NMH publications 2018:1. Oslo: Norges Musikkhøgskole.

Kulturdepartementet. (2016). Betänkande av kulturskoleutredningen. En inkluderande kulturskola på egen grund. SOU 2016:69. Stockholm: Kulturdepartementet.

Kulturskoleutvalget. (2010a). Kulturskoleløftet - kulturskole for alle. Oslo: Kunnskapsdepartementet. Nedlastet fra: https:/www.regjeringen.no/globalassets/upload/kd/vedlegg/rapporter/kulturskoleloeftet_ok.pdf

Kulturskoleutvalget. (2010b). Kulturskoleundersøkelsen 2010. Hentet fra: http://www.noku.no/sfiles/9/30/1/file/ kulturskoleutvalget-kortrapport-ferdig.pdf

Kunnskapsdepartementet. (2015). Kompetanse for kvalitet. Strategi for videreutdanning for lerere og skoleledere frem mot 2025. Hentet fra https://www.regjeringen.no/contentassets/731323c71aa34a51a6febdeb8d41f2e0/ kd_kompetanse-for-kvalitet_web.pdf

Lagerstrøm, B. O., Moafi, H., \& Revold, M. K. (2014). Kompetanseprofil i grunnskolen: Hovedresultater 2013/2014. Hentet fra: https://www.ssb.no/utdanning/artikler-og-publikasjoner/_attachment/197751

Lund, T., Rotvold, L. A., Skrøvset, S., Stjernestrøm, E., \& Tiller, T. (2010). Dialogkonferansen som læringsarena og pedagogisk utviklingsverktøy. Tidsskriftet FoU i praksis, 4(1), 47-64.

Norsk kulturskoleråd. (2016). Rammeplan for kulturskolen. Mangfold og fordypning. Hentet fra: https://www. kulturskoleradet.no/rammeplanseksjonen/rammeplanen

NOU 2015:8. (2015). Fremtidens skole. Fornyelse av fag og kompetanser. Oslo: Kunnskapsdepartementet.

Rønning, R. J., Rønningen, A., \& Westby, I. A. (2017). Høringsprosess for kapittel $3 i$ Rammeplan for kulturskolen - fase 1 (fagplanpiloten). Trondheim: Norsk kulturskoleråd. Hentet fra: https://www.kulturskoleradet.no/_ extension/media/4647/orig/2017\%20Fagplanpilot\%20rapport.pdf

Rønningen, A. (2017). The Norwegian municipal music and art schools in the light of community music. International fournal of Community Music, 10(1), 33-43. doi:10.1386/ijcm.10.1.33_1

Rønningen, A. (2018). Kompetansekartlegging for kulturskolene i Buskerud, Telemark og Vestfold (BTV). Hentet fra: https:/www.kulturskoleradet.no/_extension/media/5605/orig/2018Kompetansekartlegging-BTV.pdf

Waagen, W. (2011). Kulturskole: profesjon og bcrekraft. Oslo: Gyldendal akademisk.

Waagen, W. (2016). Kulturskolelæreres kunnskapsgrunnlag, illustrert ved instrumentallærerne. I Nordisk musikkpedagogisk forskning. Årbok 17, 2016, 227-242.

Westby, I. A. (2017a). Den profesjonelle kulturskolelæreren i et sammensatt yrkesfelt. I S. G. Nielsen, \& Ø. Varkøy (Red.), Utdanningsforskning i musikk - didaktiske, sosiologiske og filosofiske perspektiver - [Festskrift til Geir fohansen]. NMH-publikasjoner 2017:10. Vol. 1 (s. 115-125). Oslo: Norges Musikkhøgskole.

Westby, I. A. (2017b). Undervisningsfaget musikk i kulturskole og grunnskole - to sider av samme sak? I E. Angelo, A. Rønningen, \& R. J. Rønning (Red.), Forskning og utvikling i kulturskolefeltet. Den doble regnbuen: IRISforsk (s. 134-156). Oslo: Cappelen Damm Akademisk. DOI: https://doi.org/10.23865/noasp.21 